\title{
Peat Properties, Dominant Vegetation Type and Microbial Community Structure in a Tropical Peatland
}

\author{
N. T. Girkin ${ }^{1,2} \cdot$ R. A. Lopes dos Santos ${ }^{3}$ - C. H. Vane ${ }^{3} \cdot$ N. Ostle ${ }^{4}$ - B. L. Turner ${ }^{5} \cdot$ S. Sjögersten ${ }^{2}$
}

Received: 1 October 2019 / Accepted: 6 March 2020 / Published online: 20 April 2020

(C) The Author(s) 2020

\begin{abstract}
Tropical peatlands are an important carbon store and source of greenhouse gases, but the microbial component, particularly community structure, remains poorly understood. While microbial communities vary between tropical peatland land uses, and with biogeochemical gradients, it is unclear if their structure varies at smaller spatial scales as has been established for a variety of peat properties. We assessed the abundances of PLFAs and GDGTs, two membrane spanning lipid biomarkers in bacteria and fungi, and bacteria and archaea, respectively, to characterise peat microbial communities under two dominant and contrasting plant species, Campnosperma panamensis (a broadleaved evergreen tree), and Raphia taedigera (a canopy palm), in a Panamanian tropical peatland. The plant communities supported similar microbial communities dominated by Gram negative bacteria (38.9-39.8\%), with smaller but significant fungal and archaeal communities. The abundance of specific microbial groups, as well as the ratio of caldarchaeol:crenarchaeol, isoGDGT: brGDGTs and fungi:bacteria were linearly related to gravimetric moisture content, redox potential, $\mathrm{pH}$ and organic matter content indicating their role in regulating microbial community structure. These results suggest that tropical peatlands can exhibit significant variability in microbial community abundance even at small spatial scales, driven by both peat botanical origin and localised differences in specific peat properties.
\end{abstract}

Keywords PLFA · GDGT · Tropical peat · Microbial community structure $\cdot$ Wetland

\section{Introduction}

Tropical peatlands are a critical part of the global carbon cycle representing a significant sink carbon containing $15-19 \%$ of the global peat carbon stock (Dargie et al. 2017; Page et al. 2011). Tropical wetlands in general are large sources of greenhouse gas emissions (GHGs), with annual emissions of up to $4540 \mathrm{Tg}$ carbon dioxide $\left(\mathrm{CO}_{2}\right)$ and $90 \mathrm{Tg}$ methane $\left(\mathrm{CH}_{4}\right)$

N. T. Girkin
nicholas.girkin@gmail.com

1 Environment and Agrifood, Cranfield University, Cranfield MK43 0AL, UK

2 School of Biosciences, University of Nottingham, Nottingham NG7 2RD, UK

3 Centre for Environmental Geochemistry, British Geological Survey, Keyworth NG12 5GG, UK

4 Lancaster Environment Centre, Lancaster University, Lancaster LA1 4YQ, UK

5 Smithsonian Tropical Research Institute, Apartado 0843-03092, Balboa, Ancon, Republic of Panama
(Sjögersten et al. 2014). Plants are key in regulating GHG emissions, as species specific litter inputs define initial peat properties (Cooper et al. 2019; Upton et al. 2018) and rates of decomposition (Hoyos-Santillan et al. 2016b; HoyosSantillan et al. 2015). Plant inputs of oxygen and carbon, in the form of root exudates, have also been identified as critical regulators (Girkin et al. 2018c; Hoyos-Santillan et al. 2016a). Water table height and peat temperature are key environmental regulators, with the former determining whether anaerobic or aerobic decomposition pathways dominate, affecting the balance of $\mathrm{CO}_{2}$ versus $\mathrm{CH}_{4}$ production, and the latter determining the rate of biological processes (Girkin et al. 2020; Hooijer et al. 2012; Hooijer et al. 2010; Jauhiainen et al. 2005).

While peat organic matter properties have previously been found to vary substantially between dominant vegetation types (Sjögersten et al. 2011; Upton et al. 2018), peat properties can also vary on much smaller scales, between both plant species and with distance from plant stems (Girkin et al. 2019). Overall spatial variability of inputs and properties is therefore very high, with a microtopography that is also frequently visually highly heterogeneous, featuring a series of hummocks and hollows, the former of which are formed 
predominantly by plant roots and rise above the surface of the water table, the latter of which are frequently permanently inundated. Similarly, microbial community structure has previously been found to vary between dominant vegetation types, driven predominantly by biogeochemical gradients (Troxler et al. 2012). However, smaller-scale variability in microbial community structure driven by individual plants has never been assessed in tropical peatlands.

To date, studies assessing microbial communities in tropical forests have indicated substantial differences in microbial community structure and activity on the conversion of primary or secondary swamp forest to plantation agriculture (Krashevska et al. 2015; Nurulita et al. 2016). Analysis of the 16S rRNA sequence of peats have indicated that primary tropical swamp forest features a diverse community including obligate anaerobes such as methanogenic archaea (Kanokratana et al. 2011), with bacterial community composition closely related to the availability of limiting nutrients such as phosphorus (Troxler et al. 2012). In general, most studies have identified high abundances of Gram negative bacteria, particularly Acidobacteria, and relatively low fungal abundance (Chambers et al. 2016; Jackson et al. 2009; Troxler et al. 2012). Changes in microbial community structure with depth in tropical peatlands have also been observed, with archaeal abundance more limited at increased depth (Jackson et al. 2009). Differences in microbial community structure between seasons and primary and secondary swamp forest in Malaysia, assessed through changes in specific phospholipid fatty acid (PLFA) biomarkers, have also been reported. Components of the microbial community, Gram positive and Gram negative bacteria, have in turn been positively correlated with $\mathrm{CO}_{2}$ and $\mathrm{CH}_{4}$ emissions respectively (Dhandapani et al. 2019). Assessing microbial community composition is therefore important in interpreting greenhouse gas dynamics within peatlands.

PLFA biomarker analysis is a widely used technique for determining soil microbial community structure, specifically the relative abundances of fungi, and Gram positive and Gram negative bacteria (Frostegard et al. 2011), with results broadly comparable to those derived from 16S rRNA gene metabarcoding for discerning microbial community structure (Orwin et al. 2018). Similarly, glycerol dialkyl glycerol tetraether (GDGT) can be used to characterise archaea as well as specific bacterial communities (Schouten et al. 2007), with biomarkers identified in peats (Schouten et al. 2000; Weijers et al. 2006; Zheng et al. 2015), sediments (Pancost and Damste 2003) and soils (Dirghangi et al. 2013). Both PLFAs and GDGTs are membrane spanning lipids which differ broadly in structure and size between microbial groups, thus allowing specific biomarkers to be attributed to individual communities, although this has not always been consistently applied (De Deyn et al. 2011; Nottingham et al. 2009; Tavi et al. 2013; Yao et al. 2015). Lipid biomarker analysis has several advantages over other methods of characterising soil microbial communities, including both DNA and RNA extractions. First, DNA can persist long after cell death whereas phospholipids are rapidly degraded, which means that DNA based methods of assessing total biomass therefore include a certain fraction of microbial necromass (White et al. 2009). Moreover, cell membrane lipid biomarker abundances respond to both internal and external environmental changes, meaning that PLFA and GDGT analyses provide information on both the phenotype and activity of microbial communities (Frostegard et al. 2011; Ramsey et al. 2006; Willers et al. 2015).

Recent microbial community studies in peatlands using GDGT analysis have predominantly focussed on its use as a biomarker in paleoclimate studies (Zheng et al. 2015), but distributions of branched GDGTs (brGDGTs) have also been applied as a peat-specific temperature and $\mathrm{pH}$ proxies (Naafs et al. 2017). brGDGTs are also thought to be produced by heterotrophic bacteria dwelling in anoxic soils, with Acidobacteria a key taxa (Damste et al. 2011; dos Santos and Vane 2016). Similarly, isoprenoid GDGTs (isoGDGTs) are broad indicators of archaeal abundance, with caldarchaeol (GDGT-0) abundance suggested as a biomarker for methanogenic archaea (Zheng et al. 2015).

In this study, we applied PLFA and GDGT biomarker analyses to assess microbial community structure in surface peats associated with two plant species, Campnosperma panamensis, a broadleaved evergreen tree, and Raphia taedigera, a canopy palm. These two species represent two dominant components of plant community structure for the Changuinola peat deposit, Panama. Peat derived from their inputs has previously been reported to vary significantly in terms of organic matter properties on both large $(\mathrm{km})$ and small scales $(\mathrm{m})$ across the peatland dome (Girkin et al. 2019; Upton et al. 2018), feature varying litter decomposition rates (Hoyos-Santillan et al. 2015), and autotrophic and heterotrophic respiration components (Girkin et al. 2018a). We subsequently compared microbial community structure and abundance to key environmental variables to relationships between dominant vegetation type, bulk peat properties and microbial communities. We hypothesised that: i) peats derived from contrasting botanical origins would feature distinct microbial community structure; ii) biomarker abundance would be determined by key peat biogeochemical properties including $\mathrm{pH}$, redox potential, substrate availability $(\mathrm{C}: \mathrm{N}$ and organic matter content) and gravimetric moisture content.

\section{Materials and Methods}

\section{Study Sites}

This study was conducted using peat samples collected in May 2016 in the $80 \mathrm{~km}^{2}$ ombrotrophic Changuinola 
peatland in Bocas del Toro province, Panama. Peat formation began 4000-5000 years ago and has resulted in a central peat dome up to $8 \mathrm{~m}$ deep (Phillips et al. 1997). The site is dominated by seven successive plant phasic communities beginning with a coastal belt of Rhizophora mangle (Linnaeus) mangrove, succeeded by Raphia taedigera (Mart.) dominated palm swamp, a mixed species forest swamp comprising $R$. taedigera and Campnosperma panamensis (Stand1.), a C. panamensis dominated forest, a stunted $C$. panamensis forest, and a Myrica-Cyrilla bog-plain (Phillips et al. 1997).

The Changuinola peat deposit has previously been extensively characterised in terms of species diversity and abundances (Sjögersten et al. 2011), nutrient availability (Sjögersten et al. 2011; Troxler et al. 2012), and peat organic chemistry (Upton et al. 2018). Species composition and abundances have been reported to change over relatively short distances matching gradients in nutrient status towards the centre of the dome. Briefly, $R$. taedigera monodominant stand has a low Shannon diversity index (1.13) and low stem abundance (106 stems per hectare). The site has total phosphorus of $0.957 \mathrm{mg} \mathrm{P}$ $\mathrm{g}^{-1}$ higher than other stands at the site (Sjögersten et al. 2011). In contrast, C. panamensis monodominant stand has a higher mean stem density of 212 stems per hectare and a higher diversity of 1.53 . Phosphorus concentrations are lower compared to $R$. taedigera $\left(0.668 \mathrm{mg} \mathrm{P} \mathrm{g}^{-1}\right)$, matching a gradual decline in nutrient concentrations towards the central peat dome. Details of other nutrient and vegetation trends across the entire dome are reported in Phillips et al. 1997, Sjögersten et al. 2011 and Troxler et al. 2012.

Mean annual temperature was $26^{\circ} \mathrm{C}$ in the 13 years prior to sampling, with mean annual rainfall of $3207 \mathrm{~mm}$. During the sampling period mean air temperature was $25^{\circ} \mathrm{C}$ and rainfall was $280 \mathrm{~mm}$. Soil temperature was $25^{\circ} \mathrm{C}$. There is no limited seasonality in the region, with the water table remaining close to the surface throughout the year. There are, however two periods of lower rainfall between February and April, and September and October (Wright et al. 2011). During sampling, the water table height was consistent, fluctuating $\pm 5 \mathrm{~cm}$. Central areas of the dome are consistently flooded throughout the year.

\section{Peat Sampling and Characterization}

The microtopography under both $C$. panamensis and $R$. taedigera plants featured a mix of shallow water pools (hollows) and raised areas (hummocks), the formation of which is primarily driven by the presence pneumatophores and roots. Ten peat samples were collected from peat under both $C$. panamensis trees and $R$. taedigera palms using a hand trowel to excavate the acrotelm (approximately $0-10 \mathrm{~cm}$ ).
Samples were collected from slight depressions between roots which at the time of sampling were water-saturated but not flooded. Samples were stored in zip-lock bags and transported to the University of Nottingham where they were stored at $4{ }^{\circ} \mathrm{C}$ prior to analysis.

Sub-samples from each site were used to characterise physiochemical properties in the laboratory. Peat moisture content was determined through gravimetric analysis of the mass of water lost from $10 \mathrm{~g}$ wet weight peat oven dried at $105{ }^{\circ} \mathrm{C}$ for $24 \mathrm{~h}$. Organic matter content was determined as the mass lost after ignition for $7 \mathrm{~h}$ at $550{ }^{\circ} \mathrm{C}$. Total peat carbon $(\mathrm{C})$ and total nitrogen $(\mathrm{N})$ were determined from $0.2 \mathrm{~g}$ of dry, homogenised peat combusted using a total element analyser (Flash EA 1112, CE Instruments, Wigan, UK). Peat $\mathrm{pH}$ and redox potential were measured using a Hanna $209 \mathrm{pH}$ meter coupled with separate $\mathrm{pH}$ and redox probes. Electrical conductivity was measured simultaneously using a conductivity meter.

\section{PLFA Analysis}

PLFAs were extracted from 20 peat samples following the Bligh and Dyer (1959). Total lipids were extracted from $500 \mathrm{mg}$ of freeze-dried soils using citrate buffer $(0.15 \mathrm{M}$, $\mathrm{pH} 4), 1.9 \mathrm{ml}$ chloroform $\left(\mathrm{CHCl}_{3}\right), 3.8 \mathrm{ml}$ methanol $(\mathrm{MeOH})$ and $2 \mathrm{ml}$ Bligh and Dyer reagent $\left(\mathrm{CHCl}_{3}: \mathrm{MeOH}\right.$ : citrate buffer; 1: 2: 0.8 volume ratio). Extracts were vortexed for one minute and left at room temperature to separate for two hours. Subsequently, extracts were centrifuged for $10 \mathrm{~min}$ at a relative centrifugal force of 650 before the supernatant was transferred to a $\mathrm{CHCl}_{3}$ rinsed glass tube. This step was repeated twice to ensure complete extraction of lipids from the soil pellet. Citrate buffer and chloroform (1:1 volume ratio) were added and left overnight to allow separation of aqueous and organic phases. The chloroform layer was transferred to a clean glass tube and blown dry under a stream of $\mathrm{N}_{2}$ at room temperature (Bligh and Dyer 1959).

Lipids were separated using a silica solid phase extraction cartridge. The cartridge column was rinsed first with $15 \mathrm{ml}$ methanol followed by $2.5 \mathrm{ml}$ chloroform. The dry lipid extract was re-suspended in $0.5 \mathrm{ml}$ chloroform and added to the column. Lipids were separated into neutral lipids, glycolipids and phospholipid fractions using chloroform, acetone and methanol solutions respectively. The PLFA fraction was collected and evaporated under a stream of $\mathrm{N}_{2}$ at $36{ }^{\circ} \mathrm{C}$.

Phospholipid samples were re-suspended in $1 \mathrm{ml} \mathrm{MeOH}$ : toluene (1:1 volume ratio) and trans-esterified to fatty acid methy esthers (FAMEs) using $1 \mathrm{ml} 0.2 \mathrm{M} \mathrm{KOH}$ dissolved in methanol. For liquid extraction, $2 \mathrm{ml}$ of hexane:chloroform (4:1 volume ratio), $0.3 \mathrm{ml}$ acetic acid $(1.0 \mathrm{M})$, and $2 \mathrm{ml}$ ultrapure water were added. $\mathrm{C} 13$ and $\mathrm{C} 19$ internal standards were 
added to the samples before evaporating FAMEs under a stream of compressed $\mathrm{N}_{2}$ and re-suspension in hexane prior to GC analysis. PLFAs were identified and quantified using gas-chromatography.

Standard PLFA nomenclature is applied $(\mathrm{A}: \mathrm{B} \omega \mathrm{C})$ where $\mathrm{A}$ is total number of carbon atoms, $\mathrm{B}$ is the number of double bonds, and $\mathrm{C}$ is the position of double bond from the methyl end of the molecule. ' $\mathrm{C}$ ' and ' $\mathrm{T}$ ' indicate cis and trans isomers, and ' $A$ ', ' $I$ ' indicates iso- and anteiso-, and 'Me' and ' $\mathrm{Cy}$ ' indicate methyl groups and cyclopropyl rings respectively (Kong et al. 2011). C15:0i, C15:0a, C16:0i, C17:0i and C17:0a PLFA biomarkers were assigned to Gram positive bacteria. $\mathrm{C} 16: 1 \omega 7, \mathrm{C} 17: 0, \mathrm{C} 18: 1 \omega 7$, and 7,8Cy-C19:0 were assigned to Gram negative bacteria. Fungal PLFA biomarkers

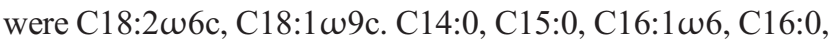
$\mathrm{C} 17: 1 \omega 8,10 \mathrm{Me}-\mathrm{C} 16: 0, \mathrm{C} 17: 1,10 \mathrm{Me}-\mathrm{C} 17: 0$, and C18:0, biomarkers were unclassified due to a lack of specificity to any microbial group.

\section{GDGT Analysis}

GDGTs were extracted from 20 freeze-dried peat samples (500 mg) using an Accelerated Solvent Extractor (ASE) 200 , Dionex, operated at $100{ }^{\circ} \mathrm{C}$ and $7.6 \times 10^{6} \mathrm{~Pa}$ with a mixture of dichloromethane (DCM): methanol $(\mathrm{MeOH})(9: 1, \mathrm{v}: \mathrm{v})$ to obtain a total lipid extract (TLE). Internal standards squalane and $\mathrm{C}_{46}$ GDGTs were added to the TLE, which was subsequently separated into an apolar and polar fraction in an alumina oxide column $\left(\mathrm{Al}_{2} \mathrm{O}_{3}\right)$, using $n$-hexane/DCM 9:1, and methanol/DCM 1:1 as eluents. The polar fractions were filtered through a polytetrafluoroethylene filter (PTFE $0.45 \mu \mathrm{m})$ and analysed using a Thermo TSQ Quantiva coupled to an Ultimate 3000 series U-HPLC following a slightly modified method of Schouten et al. (2007) described in Lopes dos Santos and Vane (2016). Shortly, separation was achieved on a Prevail Cyano column $(2.1 \times 150 \mathrm{~mm}, 3 \mathrm{Am}$; Alltech, Deerfield, IL, USA), maintained at $30^{\circ} \mathrm{C}$. Tetraethers were eluted isocratically with $99 \% \mathrm{~A}$ and $1 \%$ B for $5 \mathrm{~min}$, followed by a linear gradient to $1.8 \% \mathrm{~B}$ in $45 \mathrm{~min}$, where $\mathrm{A}$ is

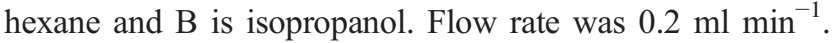
Detection was achieved using atmospheric pressure positive ion chemical ionization mass spectrometry (APCI-MS) of the eluent. Conditions for APCI-MS were as follows: sheath gas 20 , auxiliary gas 2 , ion transfer tube temperature $325^{\circ} \mathrm{C}$, vaporiser temperature $400{ }^{\circ} \mathrm{C}$, pos. Ion discharge 2 . Relative GDGT distributions were determined by integrating the summed peak areas in the respective $[\mathrm{M}+\mathrm{H}]^{+}$. IsoGDGTs (GDGT-0, GDGT-1, GDGT-2, GDGT-3, crenarchaeol and isocrenarchaeol) were assigned to archaea, and brGDGTs (brGDGT-IIIa, brGDGT-IIa, brGDGT-IIb, brGDGT-IIc, brGDGT-Ia, brGDGT-Ib and brGDGT-Ic) were assigned to bacteria (Fig. 1).

\section{Statistical Analysis}

A one-way ANOVA was used to assess differences properties and biomarker abundances between peat types. Principal component analyses (PCAs), based on correlation matrices, were used to visualise microbial community profiles for both peat types and were applied separately for individual PLFA and GDGT biomarkers. Backwards stepwise regression was used to identify which biogeochemical variables best described PLFA and GDGT biomarker abundance for specific groups of microorganisms. The groups used were total, Gram positive and Gram negative bacteria, and fungi calculated from PLFA biomarker abundance and PC-1 and PC-2 from the PLFA PCA, archaea (total IsoGDGTs) and bacteria (total brGDGTs) from GDGT biomarker abundance, and PC-1 and PC-2 from the GDGT PCA. For each regression, the maximal model comprised all measured biogeochemical properties included $\mathrm{pH}$, redox potential, electrical conductivity, total carbon and nitrogen, moisture content and organic matter content. Non-significant variables were eliminated individually using backwards elimination regression using $p>0.05$ as a cut-off. Non-linear models were also tested using the same data. $R^{2}$ values reported in text are adjusted $R^{2}$ derived from multiple regression models. All statistical analyses were conducted in GenStat v17.1, and figures produced in GraphPad Prism v7.04.

\section{Results}

\section{Peat Properties}

Peats from under both species were acidic, with $\mathrm{pH}$ significantly lower under $C$. panamensis (4.2) compared to $R$. taedigera (4.7) $(p<0.005$, Table 1). Electrical conductivity was low, and both peat types were weakly reducing $(<$ $300 \mathrm{mV}$ ) with neither property differing significantly between species. Moisture content and organic matter content were high for both peats (> 80\%), with organic matter content significantly greater in $C$. panamensis peats $(92.7 \%)$ compared to $R$. taedigera $(87.7 \%)(p<0.05)$. Total carbon $(p<0.001)$ and total nitrogen $(\mathrm{p}<0.05)$ were both greater in $C$. panamensis peats $(40.8 \%$ and $2.4 \%$ ) compared to $R$. taedigera $(35.3 \%$ and $2.1 \%)$. C:N ratios were similar between peat types (17.217.3).

\section{Microbial Community Composition}

Microbial communities from under both plant species had broadly profiles (Fig. 2a). Total PLFA biomarker abundance was somewhat higher in $C$. panamensis peats $(74.7 \pm$ $\left.7.0 \mu \mathrm{g} \mathrm{g}^{-1}\right)$ compared to $R$. taedigera peats $(62.3 \pm$ $4.9 \mu \mathrm{g} \mathrm{g}^{-1}$ ) but there were no significant differences between 


\section{BrGDGTs}
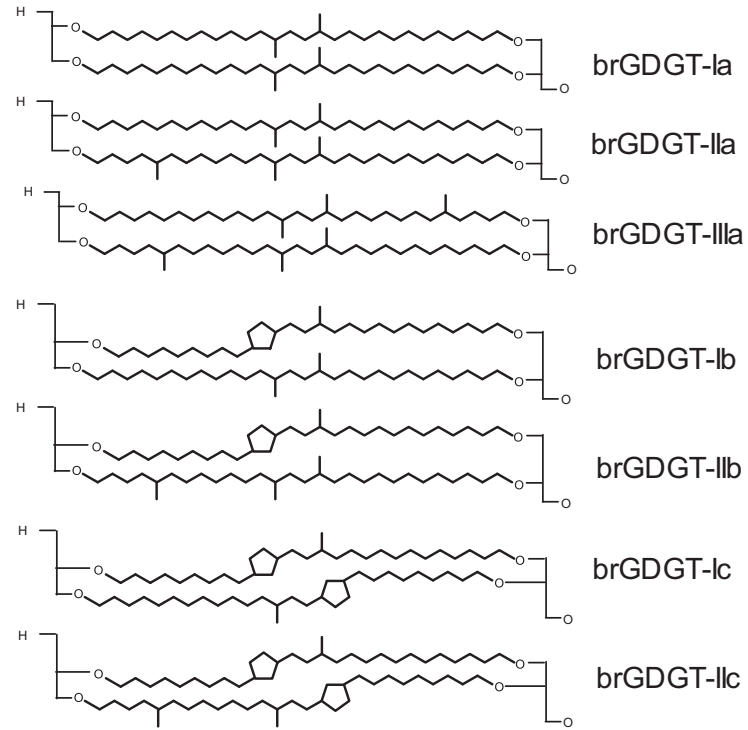

Fig. 1 Molecular structure of identified br- and isoGDGTs

peat types for any specific PLFA biomarker groupings (Fig. $2 b)$. The ratios of fungi:bacteria $(0.12-0.13)$ and Gram positive:Gram negative bacteria $(0.65-0.68)$ were consistent between peat types. Fungal biomarkers were the smallest group relative to total biomarker abundance (Fig. 2c). Gram negative biomarkers were most abundant, accounting for $38.9-39.8 \%$ of total biomarkers. PCA broadly separated both peat types, with separation along the first principal component (PC-1) separated by C15:0i, as well as several non-specific biomarkers. PC-2 separated loadings by $\mathrm{C} 16: 1 \omega 7, \mathrm{C} 16: 0$, 10Me-C17:0, amongst others. Collectively PC-1 and PC-2 accounted for $77 \%$ of variance (Fig. $2 \mathrm{~d}$-e).

GDGT biomarker profiles indicated only limited differences in archaea (isoGDGTs) and bacteria (brGDGTs) abundance between peats (Fig. 3a) with no significant differences $(p>0.05)$. GDGT-0 was the most abundant isoGDGT for both peat types, and brGDGT-Ia was the most abundant brGDGT. Overall brGDGT abundance was greater than isoGDGT

Table 1 Biogeochemical properties from $C$. panamensis and R. taedigera derived peats. Means \pm one $\mathrm{SE}(n=10)$. $*=p<0.05$, ** $=$ $p<0.005, * * * p<0.001$

\begin{tabular}{lcc}
\hline Peat botanical origin & C. panamensis & R. taedigera \\
\hline $\mathrm{pH}$ & $4.2 \pm 0.07$ & $4.7 \pm 0.1 * *$ \\
Conductivity $\left(\mu \mathrm{S} \mathrm{cm}^{-1}\right)$ & $63.3 \pm 20.8$ & $85.9 \pm 10.3$ \\
Redox potential $(\mathrm{mV})$ & $226.4 \pm 9.0$ & $239.9 \pm 2.2$ \\
Moisture content $(\%)$ & $86.0 \pm 1.2$ & $84.8 \pm 0.9$ \\
Organic matter $(\%)$ & $92.7 \pm 1.6$ & $87.7 \pm 1.3 *$ \\
Total carbon $(\%)$ & $40.8 \pm 1.1$ & $35.3 \pm 1.6 * * *$ \\
Total nitrogen $(\%)$ & $2.4 \pm 0.1$ & $2.1 \pm 0.1 *$ \\
C:N & $17.3 \pm 0.8$ & $17.2 \pm 0.3$ \\
\hline
\end{tabular}

\section{isoGDGTs}
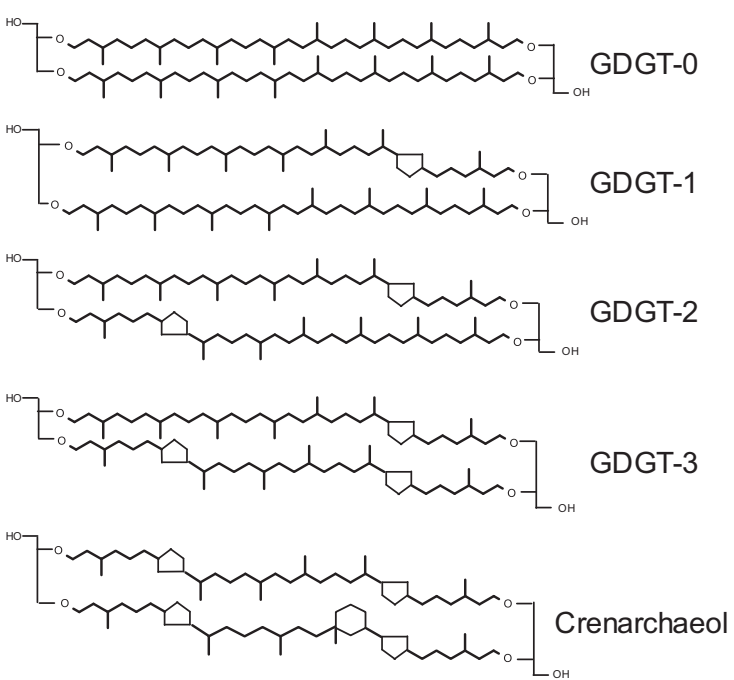

abundance (Fig. 3b). There were no significant differences in total abundances of isoGDGTs, or brGDGTs between peat types $(\mathrm{p}>0.05)$. The ratio of caldarchaeol:crenarchaeaol was greater under C. panamensis (13.0) than for R. taedigera (6.0) but was not significantly different $(\mathrm{p}>0.05)$. PCA conducted using GDGT biomarkers again indicated limited broad scale differences in microbial community structure between peat types. With the exception of crenarchaea, the second principle component predominantly separated isoGDGTs from brGDGTs. Collectively PC-1 and PC-2 accounted for $72 \%$ of variance (Fig. 3c-d).

\section{Environmental Regulation of Microbial Communities}

The results of multiple linear regression indicated several significant relationships between key environmental variables and biomarker abundance (Table 2). A significant positive linear relationship was identified between fungi:bacteria and redox potential $(p<0.05)$. In addition, a significant positive linear relationship was identified between total carbon and PLFA PC-2 $(p<0.001)$. Significant relationships were also identified between GDGT-0 abundance and $\mathrm{pH}(p<0.05)$, and moisture content $(p<0.01)$, with decreasing $\mathrm{pH}$ but increasing moisture content associated with greater abundance. Similar relationships were identified for GDGT PC-2 ( $\mathrm{p}<$ $0.05)$. Crenarchaeol abundance decreased significantly with increasing organic matter content $(\mathrm{p}<0.01)$. Caldarchaeol:crenarchaeaol $(\mathrm{p}<0.05)$ and isoGDGT abundance $(\mathrm{p}<0.05)$ both increased significantly with moisture content. The ratio of iso:brGDGTs, however, was significantly related to $\mathrm{pH}(\mathrm{p}<0.05)$, the ratio decreasing at higher, less acidic, $\mathrm{pH}$. 
Fig. 2 (a) PLFA biomarker abundance for $C$. panamensis and R. taedigera. (b) Net abundance of fungal, Gram positive $(\mathrm{G}+)$, Gram negative (G-) and unspecified PLFA biomarkers. (c) Relative abundance of fungal, Gram positive, Gram negative and unspecified PLFA biomarkers. (d) PCA loadings for PLFA biomarkers. (e) PCA scores for PLFA biomarkers. Means \pm one $\operatorname{SE}(n=5)$
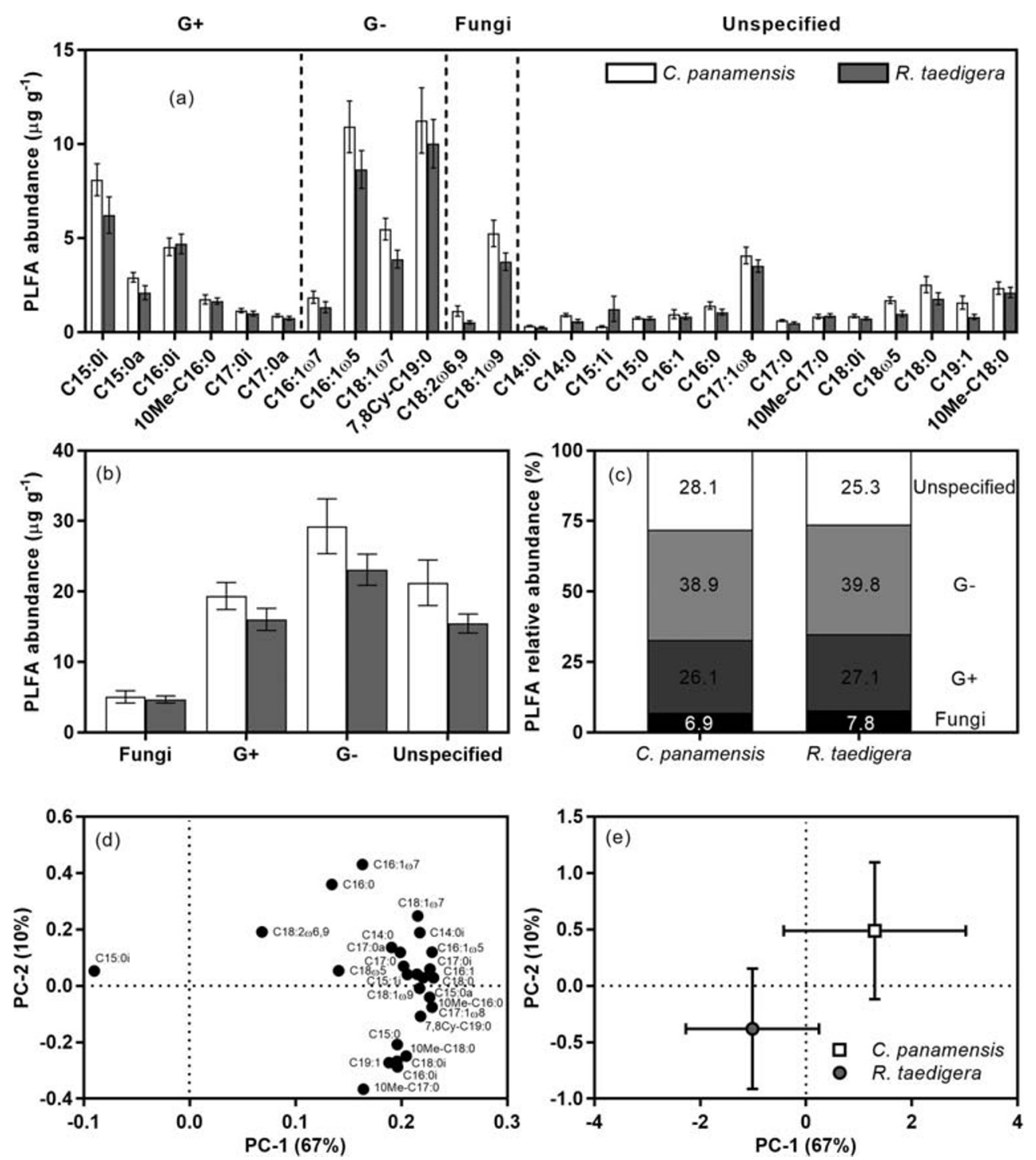

\section{Discussion}

\section{Peat Botanical Origin and Microbial Community Structure}

The PLFA and GDGT biomarker profiles of peats collected under $C$. panamensis and $R$. taedigera were broadly similar, with both microbial communities featuring a dominance of Gram negative bacteria, and lower abundances of fungi and archaea. Previous studies have identified stronger differences in microbial community structure between peats derived from contrasting botanical origins (Borga et al. 1994; Troxler et al. 2012), or have alternatively identified differences in microbial activity (Sjögersten et al. 2011). These processes are generally driven by strong gradients in peat properties (for example, $\mathrm{pH}$ and phosphorus). Substantial small-scale variation in peat properties (including $\mathrm{pH}$ and organic matter properties) has also previously been reported, with some differences between peats predominantly derived from different plant species (Girkin et al. 2019). However, it is now clear that these differences in peat properties between dissimilar plant species do not necessarily result in contrasting microbial community profiles.

The consistently high abundance of Gram negative bacteria may be driven by the dominance Acidobacteria, which are critical components of the microbial community of both tropical (Jackson et al. 2009; Troxler et al. 2012) and temperate peats (Dedysh et al. 2006), with their ubiquity reflecting their oligotrophy (Fierer et al. 2007). High abundances of brGDGTs were also found, which have previously been reported as indicative of Acidobacteria in peats and soils (Damste et al. 2011).

Methanotrophs are a key microbial group in peatlands (Hanson and Hanson 1996), with specific PLFA biomarkers previously proposed in the literature, including $\mathrm{C} 16: 1 \omega 5$, C16:1 $\omega 7, \mathrm{C} 16: 1 \omega 8 \mathrm{c}$ and $\mathrm{C} 16: 1 \omega 11 \mathrm{c}$ for type I 

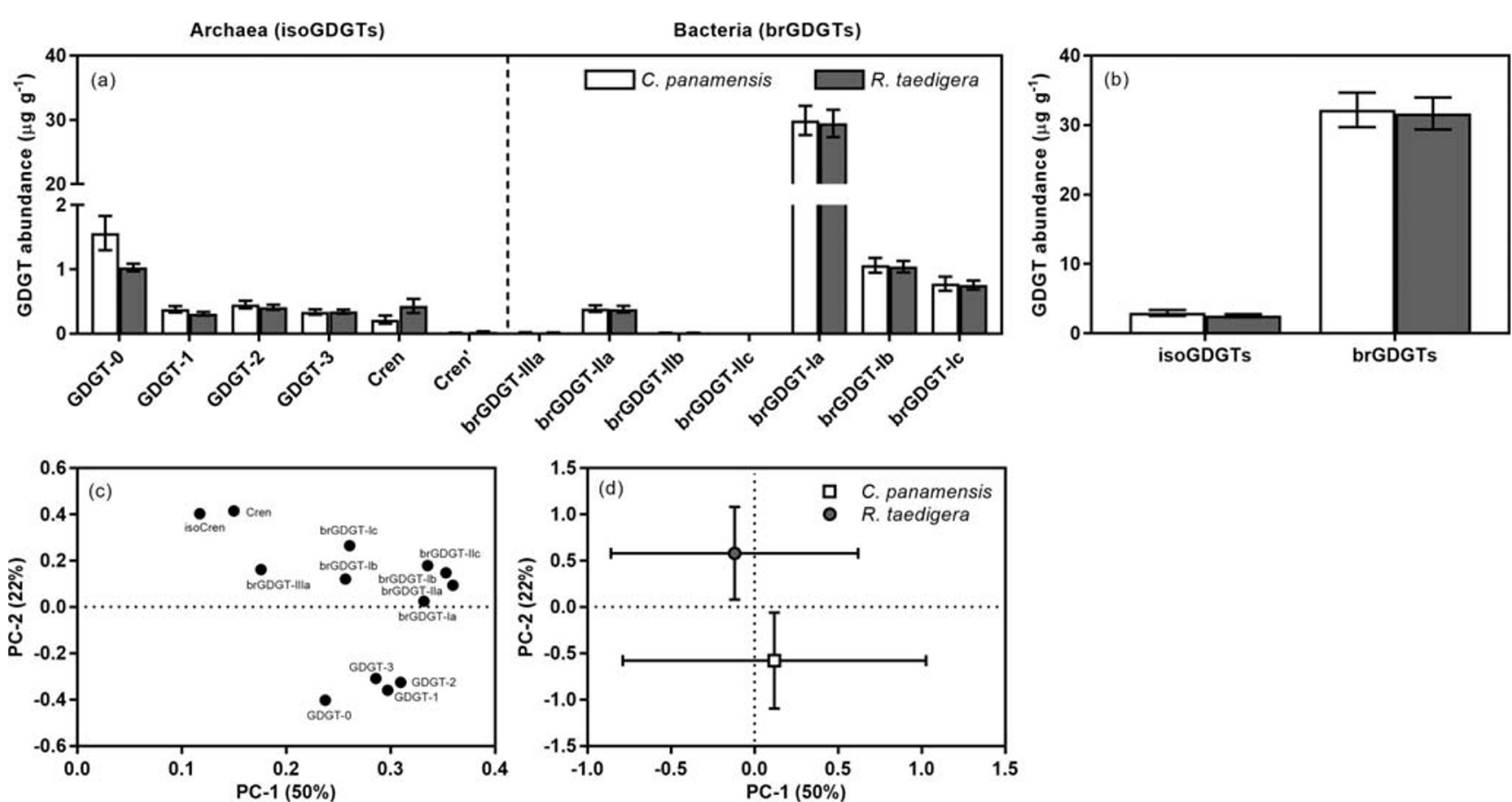

Fig. 3 (a) GDGT biomarker abundance for $C$. panamensis and $R$. taedigera. (b) Net abundance of br- and isoGDGT biomarkers. (d) PCA loadings for GDGT biomarkers. (e) PCA scores for GDGT biomarkers. Means \pm one SE $(n=5)$

methanotrophs, and $\mathrm{C} 18: 1 \omega 7 \mathrm{c}$ and $\mathrm{C} 18: 1 \omega 8 \mathrm{c}$ for type II methanotrophs (Maxfield et al. 2006; Mills et al. 2013;

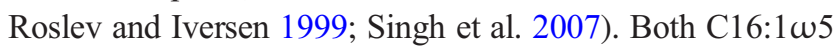
and $\mathrm{C} 18: 1 \omega 7 \mathrm{c}$ were detected in both $C$. panamensis and $R$. taedigera peats in this study and were the most abundant Gram negative biomarkers, accounting for approximately $73 \%\left(21.2 \mu \mathrm{g} \mathrm{g}^{-1}\right)$ of total Gram negative PLFA abundance (Fig. 2a). High methanotroph abundance would also imply large $\mathrm{CH}_{4}$ production, which has previously been reported from both in situ and ex situ studies of $\mathrm{CH}_{4}$ production/ fluxes (Girkin et al. 2018b; Girkin et al., 2018; Sjögersten et al. 2011).

Fungal biomarkers were generally present at much lower abundances than other PLFA biomarkers, accounting for only 7.6-7.7\% of total PLFAs, a finding possibly driven by the largely anoxic conditions. Fungi have previously been

Table 2 Backwards stepwise linear regression, reporting $p$ value and B for multiple regression models. Total carbon and total nitrogen were included in the maximal model but were not significant $(p>0.05)$. + and $-\mathrm{B}$ indicate direction of linearity

\begin{tabular}{|c|c|c|c|c|c|c|c|c|c|}
\hline Parameter & & $\begin{array}{l}\text { Fungi: } \\
\text { bacteria }\end{array}$ & $\begin{array}{l}\text { PLFA } \\
\text { PC-2 }\end{array}$ & $\begin{array}{l}\text { GDGT-0 } \\
\text { (Caldarchaeol) }\end{array}$ & Crenarchaeol & $\begin{array}{l}\text { Caldarchaeol: } \\
\text { crenarchaeol }\end{array}$ & isoGDGTs & $\begin{array}{l}\text { isoGDGT: } \\
\text { brGDGTs }\end{array}$ & $\begin{array}{l}\text { GDGT } \\
\text { PC-2 }\end{array}$ \\
\hline \multirow[t]{2}{*}{ Redox potential } & $p$ value & 0.042 & & & & & & & \\
\hline & B & +2.23 & & & & & & & \\
\hline \multirow[t]{2}{*}{ Total carbon } & $p$ value & & $<0.001$ & & & & & & \\
\hline & B & & +5.63 & & & & & & \\
\hline \multirow[t]{2}{*}{$\mathrm{pH}$} & $\mathrm{p}$ value & & & 0.02 & & & & 0.041 & 0.047 \\
\hline & B & & & -2.56 & & & & -2.20 & -2.42 \\
\hline \multirow[t]{2}{*}{ Moisture content } & $\mathrm{p}$ value & & & 0.006 & & 0.039 & 0.031 & & 0.027 \\
\hline & B & & & +3.15 & & +2.22 & +2.33 & & +2.14 \\
\hline \multirow{2}{*}{$\begin{array}{l}\text { Organic matter } \\
\text { content }\end{array}$} & $\mathrm{p}$ value & & & & 0.006 & & & & \\
\hline & B & & & & -3.10 & & & & \\
\hline F-statistic & & 4.98 & 31.7 & 9.18 & 9.6 & 4.93 & 5.44 & 4.82 & 5.84 \\
\hline d.f. & & 1,14 & 1,14 & 2,17 & 1,18 & 1,18 & 1,18 & 1,18 & 2,17 \\
\hline $\mathrm{p}$ value & & 0.042 & $<0.001$ & 0.002 & 0.006 & 0.039 & 0.031 & 0.041 & 0.012 \\
\hline Adjusted- $\mathrm{R}^{2}$ & & 0.15 & 0.65 & 0.40 & 0.27 & 0.13 & 0.14 & 0.12 & 0.26 \\
\hline
\end{tabular}


proposed as critical decomposers of organic matter in tropical peatlands, with groups identified which can decompose organic compounds ranging from simple polymers to complex phenolics including lignins and tannins (Thormann 2006). Woody wetland plants frequently form mutualisms with arbuscular mycorrhizal fungi (AMF), including in mangrove swamps (Wang et al. 2010) and in high altitude Andean wetlands (Vanesa et al. 2013) amongst others (Xu et al. 2016), although AMF biomarkers were not identified in this study.

Overall, archaea (isoGDGT) biomarkers were present at relatively low concentrations compared to bacteria (brGDGT) biomarkers, accounting for up to $8 \%$ of total GDGT compounds (Fig. 3b). This low abundance may, in part, be driven by regular changes in water table height at the site (-20-9 cm from February - May 2016), resulting in alternating oxic and anoxic conditions (Weijers et al. 2006). Low archaeal abundances have previously been reported in surface tropical peats, with archaea accounting for only $1.6 \%$ of the total microbial community in a peat swamp forest in Thailand, as identified by pyrosequencing (Kanokratana et al. 2011), although much higher abundances have been reported with parity with total bacteria (Espenberg et al. 2018).

The ratio of caldarchaeol:crenarchaeol has previously been reported as a good indicator of whether GDGTs in soils and sediments are dominated by methanogenic or nonmethanogenic Euryarchaeota, with higher ratios (> 1.4) indicating the production of caldarchaeol and thus the presence of methanogenic archaea (Zhang et al. 2016). Mean ratios were 13.0 and 6.0 under $C$. panamensis and $R$. taedigera respectively, likely explaining the high $\mathrm{CH}_{4}$ production potential of the peat soils previously reported (Girkin et al. 2018c; HoyosSantillan et al. 2016b). This ratio has also been explicitly linked to the concentrations of dissolved oxygen in sediments (Zhang et al. 2016), and in this study was significantly correlated with soil moisture content (Table 2). High relative abundance of methanogenic archaea may explain high $\mathrm{CH}_{4}$ surface fluxes previously reported from the Changuinola deposit (Wright et al. 2013a), and would likely also support the large methanotroph community identified in this study from

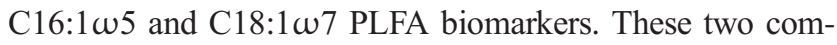
munities likely coexist in low oxygen and high oxygen microsites throughout the peat profile, with oxygen inputs from surface diffusion and root inputs (Girkin 2018).

\section{Environmental Regulation of Microbial Community Structure}

While microbial community structure did not differ between peat types, variation in several peat properties was key in determining the abundance of several microbial groups. Redox potential and $\mathrm{pH}$ were identified as significant regulators of caldarchaeol:crenarchaeol isoGDGTs:brGDGTs, fungi:bacteria, and isoGDGT abundance (Table 2). Both variables are closely linked, with redox potential, measuring the activity of electrons within the peat, and $\mathrm{pH}$ assessing proton activity (Reddy and DeLaune 2008). Redox potential is also closely linked to soil moisture content, as waterlogged soils are low in oxygen, except for inputs derived from root oxygen loss and atmospheric diffusion at the surface boundary (Hoyos-Santillan et al. 2016a). Plant root inputs of carbon (root exudates) are also able to directly influence peat properties, and may therefore also exert an indirect control on microbial community structure and function, but the precise effect is dependent on the composition and concentration of the input (Girkin et al. 2018b). Moreover, peat properties are also strongly linked to the properties and quantity of leaf, root and shoot inputs and the influence of their decomposition products on their immediate environment (Hoyos-Santillan et al. 2015).

The significant link between redox potential and fungi:bacteria abundance is important because under oxic conditions fungi are key decomposers (Thormann 2006). The inhibitive role of waterlogged conditions on tropical peat fungal abundance has been previously demonstrated, with significant increases in fungal gene copy numbers following a drought event (Kwon et al. 2013). Low redox potential indicates increasingly anoxic peat which may limit the presence of fungi, which are frequently obligate aerobes. Organic matter content, indicating the broad availability of substrate for microbial respiration, was also positively correlated to crenarchaeol GDGT biomarker abundance, suggesting a possible role as a limiting factor for its abundance. This may be because crenarchaeaol are limited by the availability of specific components of the available organic matter pool, which may increase in line with total organic matter availability (Girkin et al. 2019; Hodgkins et al. 2018), as it is unlikely that total organic matter content is limiting in a tropical peatland system. In addition, the significant linear regression between PLFA PC-2 and total carbon, and GDGT PC-2 and moisture content and $\mathrm{pH}$ broadly matches those of previous studies of tropical peatland microbial community structure, which have identified substrate availability ( $\mathrm{C}, \mathrm{N}$ and $\mathrm{P})$, and $\mathrm{pH}$ as key for determining diversity (Krashevska et al. 2015; Troxler et al. 2012).

Previous studies in tropical soils and peats have noted that microbial community structure and abundance can exhibit a tendency towards seasonality (Dhandapani et al. 2019; Smith et al. 2018). Tropical peatlands are subject to distinct wet and dry seasons which can exert a strong influence on water table height in particular, altering the balance between oxic and anoxic processes (Wright et al. 2013b). Peats in this experiment were collected from hollow, which, in general, are more consistently water-saturated throughout the year compared to hummocks formed by root material (Jauhiainen et al. 2005). As a consequence, we speculate that the significant relationships between redox potential and soil moisture and a variety 
of PLFA and GDGT biomarker abundances mean that seasonal changes in precipitation will influence on community structure in this ombrotrophic peatland, with potential consequences for GHG emissions. This has been previously demonstrated to be the case in temperate peatlands, with significant changes in microbial community structure with changes in water table depth (Zhong et al. 2015), and has recently been reported in two tropical peatlands in Malaysia (Dhandapani et al. 2019).

\section{Conclusion}

Our results indicate that botanical origin can result in substantial differences in peat bulk properties, specifically total carbon and nitrogen, $\mathrm{pH}$, and organic matter content. However, while many of these properties significantly affected the abundance of specific components of the peat microbial community, overall community structure did not vary significantly between peat types. The PLFA and GDGT biomarker profiles for $C$. panamensis and $R$. taedigera derived peats are amongst the first for Neotropical peatlands and indicate a dominance of Gram negative bacteria (38.9-39.8\%). Prevailing environmental conditions, particularly soil moisture content and small changes in $\mathrm{pH}$ exerted a significant control on the abundance of specific microbial groups which are known as key drivers of ecosystem GHG fluxes, including methanogens and methanotrophs. This is important in the wider context of land use change in the tropics, as these processes alter peat properties and subsequent GHG production.

Acknowledgements This work was supported by the Natural Environment Research Council [grant number NE/L002604/1], and a Smithsonian Tropical Research Institute short-term fellowship. We would also like to thank Eric Brown for his support in the field, the staff at the Smithsonian Tropical Research Institute in Panama City and Bocas Del Toro for their logistical support, and James Verran and Dr. Saul Vasquez Reina at the University of Nottingham, and Dr. Annette Ryan at Lancaster University for analytical support. CHV publishes with the permission of the Executive Director of the British Geological Survey (NERC).

Author Contributions NTG, BT, NO and SS devised the study. NTG conducted the fieldwork. NTG, RLS and CHV analysed the samples. NTG analysed the data and wrote the first draft of the manuscript. All authors contributed to subsequent revisions.

\section{Compliance with Ethical Standards}

Conflict of Interest The authors declare no competing interests.

Open Access This article is licensed under a Creative Commons Attribution 4.0 International License, which permits use, sharing, adaptation, distribution and reproduction in any medium or format, as long as you give appropriate credit to the original author(s) and the source, provide a link to the Creative Commons licence, and indicate if changes were made. The images or other third party material in this article are included in the article's Creative Commons licence, unless indicated otherwise in a credit line to the material. If material is not included in the article's Creative Commons licence and your intended use is not permitted by statutory regulation or exceeds the permitted use, you will need to obtain permission directly from the copyright holder. To view a copy of this licence, visit http://creativecommons.org/licenses/by/4.0/.

\section{References}

Bligh EG, Dyer WJ (1959) A rapid method of total lipid extraction and purification. Canadian Journal of Biochemistry and Physiology. 37: 911-917. https://doi.org/10.1139/059-099

Borga P, Nilsson M, Tunlid A (1994) Bacterial communities in peat in relation to botanical composition as revealed by phospholipid fattyacid analysis. Soil Biology \& Biochemistry 26:841-848. https://doi. org/10.1016/0038-0717(94)90300-X

Chambers LG, Guevara R, Boyer JN, Troxler TG, Davis SE (2016) Effects of salinity and inundation on microbial community structure and function in a mangrove peat soil. Wetlands 36:361-371. https:// doi.org/10.1007/s13157-016-0745-8

Cooper HV, Vane CH, Evers S, Aplin P, Girkin NT, Sjögersten S (2019) From peat swamp forest to oil palm plantations: the stability of tropical peatland carbon. Geoderma 342:109-117

Damste JSS, Rijpstra WIC, Hopmans EC, Weijers JWH, Foesel BU, Overmann J, Dedysh SN (2011) 13,16-dimethyl Octacosanedioic acid (iso-diabolic acid), a common membrane-spanning lipid of Acidobacteria subdivisions 1 and 3. Applied and Environmental Microbiology 77:4147-4154. https://doi.org/10.1128/Aem. 00466-11

Dargie GC, Lewis SL, Lawson IT, Mitchard ETA, Page SE, Bocko YE, Ifo SA (2017) Age, extent and carbon storage of the Central Congo Basin peatland complex. Nature. https://doi.org/10.1038/ nature21048

De Deyn GB, Quirk H, Oakley S, Ostle N, Bardgett RD (2011) Rapid transfer of photosynthetic carbon through the plant-soil system in differently managed species-rich grasslands. Biogeosciences 8: 1131-1139. https://doi.org/10.5194/bg-8-1131-2011

Dedysh SN, Pankratov TA, Belova SE, Kulichevskaya IS, Liesack W (2006) Phylogenetic analysis and in situ identification of Bacteria community composition in an acidic Sphagnum peat bog. Applied and Environmental Microbiology 72:2110-2117. https://doi.org/10. 1128/Aem.72.3.2110-2117.2006

Dhandapani S, Ritz K, Evers S, Yule CM, Sjögersten S (2019) Are secondary forests second-rate? Comparing peatland greenhouse gas emissions, chemical and microbial community properties between primary and secondary forests in peninsular Malaysia. Science of the Total Environment. https://doi.org/10.1016/j.scitotenv.2018.11.046

Dirghangi SS, Pagani M, Hren MT, Tipple BJ (2013) Distribution of glycerol dialkyl glycerol tetraethers in soils from two environmental transects in the USA. Organic Geochemistry 59:49-60. https://doi. org/10.1016/j.orggeochem.2013.03.009

dos Santos RAL, Vane CH (2016) Signatures of tetraether lipids reveal anthropogenic overprinting of natural organic matter in sediments of the Thames estuary, UK. Organic Geochemistry 93:68-76. https:// doi.org/10.1016/j.orggeochem.2016.01.003

Espenberg M, Truu M, Mander Ü, Kasak K, Nõlvak H, Ligi T, Oopkaup K, Maddison M, Truu J (2018) Differences in microbial community structure and nitrogen cycling in natural and drained tropical peatland soils. Scientific Reports 8:1-12. https://doi.org/10.1038/ s41598-018-23032-y

Fierer N, Bradford MA, Jackson RB (2007) Toward an ecological classification of soil bacteria. Ecology. https://doi.org/10.1890/05-1839 
Frostegard A, Tunlid A, Baath E (2011) Use and misuse of PLFA measurements in soils. Soil Biology \& Biochemistry 43:1621-1625. https://doi.org/10.1016/j.soilbio.2010.11.021

Girkin NT (2018) Tropical forest greenhouse gas emissions: root regulation of soil processes and fluxes. University of Nottingham

Girkin NT, Dhandapani S, Evers S, Ostle N, Turner BL, Sjögersten S (2020) Interactions between labile carbon, temperature and land use regulate carbon dioxide and methane production in tropical peat. Biogeochemistry 147:87-97

Girkin NT, Turner BL, Ostle N, Craigon J, Sjögersten S (2018a) Root exudate analogues accelerate $\mathrm{CO} 2$ and $\mathrm{CH} 4$ production in tropical peat. Soil Biology and Biochemistry 117:48-55. https://doi.org/10. 1016/j.soilbio.2017.11.008

Girkin NT, Turner BL, Ostle N, Sjögersten S (2018b) Root-derived CO 2 flux from a tropical peatland. Wetlands Ecology and Management 26:985-991. https://doi.org/10.1007/s11273-018-9617-8

Girkin NT, Turner BL, Ostle N, Sjögersten S (2018c) Composition and concentration of root exudate analogues regulate greenhouse gas fluxes from tropical peat. Soil biology and biochemistry 127, 280 285. S0038071718303444

Girkin NT, Vane CH, Cooper HV, Moss-Hayes V, Craigon J, Turner BL, Ostle N, Sjögersten S (2019) Spatial variability of organic matter properties determines methane fluxes in a tropical forested peatland. Biogeochemistry 142:231-245

Hanson RS, Hanson TE (1996) Methanotrophic bacteria. Microbiol. Molecular Biology Reviews 60(2):439-471

Hodgkins SB, Richardson CJ, Dommain R, Wang H, Glaser PH, Verbeke B, Winkler BR, Cobb AR, Rich VI, Missilmani M, Flanagan N, Ho M, Hoyt AM, Harvey CF, Vining SR, Hough MA, Moore TR, Richard PJH, De La Cruz FB, Toufaily J, Hamdan R, Cooper WT, Chanton JP (2018) Tropical peatland carbon storage linked to global latitudinal trends in peat recalcitrance. Nature Communications 9:113. https://doi.org/10.1038/s41467-018-06050-2

Hooijer A, Page S, Canadell JG, Silvius M, Kwadijk J, Wosten H, Jauhiainen J (2010) Current and future CO2 emissions from drained peatlands in Southeast Asia. Biogeosciences 7:1505-1514. https:// doi.org/10.5194/bg-7-1505-2010

Hooijer A, Page S, Jauhiainen J, Lee WA, Lu XX, Idris A, Anshari G (2012) Subsidence and carbon loss in drained tropical peatlands. Biogeosciences 9:1053-1071. https://doi.org/10.5194/bg-9-10532012

Hoyos-Santillan J, Craigon J, Lomax BH, Lopez OR, Turner BL, Sjögersten S (2016a) Root oxygen loss from Raphia taedigera palms mediates greenhouse gas emissions in lowland neotropical peatlands. Plant and Soil 404:47-60. https://doi.org/10.1007/ s11104-016-2824-2

Hoyos-Santillan J, Lomax BH, Large D, Turner BL, Boom A, Lopez OR, Sjogersten S (2016b) Quality not quantity: organic matter composition controls of $\mathrm{CO} 2$ and $\mathrm{CH} 4$ fluxes in neotropical peat profiles. Soil Biology \& Biochemistry 103:86-96. https://doi.org/10.1016/j. soilbio.2016.08.017

Hoyos-Santillan J, Lomax BH, Large D, Turner BL, Boom A, Lopez OR, Sjögersten S (2015) Getting to the root of the problem: litter decomposition and peat formation in lowland Neotropical peatlands. Biogeochemistry 126:115-129. https://doi.org/10.1007/s10533015-0147-7

Jackson CR, Liew KC, Yule CM (2009) Structural and functional changes with depth in microbial communities in a tropical Malaysian peat swamp Forest. Microbial ecology 57:402-412. https://doi.org/10. 1007/s00248-008-9409-4

Jauhiainen J, Takahashi H, Heikkinen JEP, Martikainen PJ, Vasander H (2005) Carbon fluxes from a tropical peat swamp forest floor. Global Change Biology. https://doi.org/10.1111/j.1365-2486. 2005.001031.x

Kanokratana P, Uengwetwanit T, Rattanachomsri U, Bunterngsook B, Nimchua T, Tangphatsornruang S, Plengvidhya V, Champreda V,
Eurwilaichitr L (2011) Insights into the phylogeny and metabolic potential of a primary tropical peat swamp Forest microbial community by metagenomic analysis. Microbial Ecology 61:518-528. https://doi.org/10.1007/s00248-010-9766-7

Kong AY, Scow KM, Córdova-Kreylos AL, Holmes WE, Six J (2011). Microbial community composition and carbon cycling within soil microenvironments of conventional, low-input, and organic cropping systems. Soil Biology and Biochemistry 43(1), 20-30

Krashevska V, Klarner B, Widyastuti R, Maraun M, Scheu S (2015) Impact of tropical lowland rainforest conversion into rubber and oil palm plantations on soil microbial communities. Biology and Fertility of Soils 51:697-705. https://doi.org/10.1007/s00374015-1021-4

Kwon MJ, Haraguchi A, Kang H (2013) Long-term water regime differentiates changes in decomposition and microbial properties in tropical peat soils exposed to the short-term drought. Soil Biology \& Biochemistry 60:33-44. https://doi.org/10.1016/j.soilbio.2013. 01.023

Maxfield PJ, Hornibrook ERC, Evershed RP (2006) Estimating highaffinity methanotrophic bacterial biomass, growth, and turnover in soil by phospholipid fatty acid C-13 labeling. Applied and Environmental Microbiology 72:3901-3907. https://doi.org/10. 1128/Aem.02779-05

Mills CT, Slater GF, Dias RF, Carr SA, Reddy CM, Schmidt R, Mandernack KW (2013) The relative contribution of methanotrophs to microbial communities and carbon cycling in soil overlying a coal-bed methane seep. FEMS Microbiology Ecology 84:474 494. https://doi.org/10.1111/1574-6941.12079

Naafs BDA, Inglis GN, Zheng Y, Amesbury MJ, Biester H, Bindler R, Blewett J, Burrows MA, Torres DD, Chambers FM, Cohen AD, Evershed RP, Feakins SJ, Galka M, Gallego-Sala A, Gandois L, Gray DM, Hatcher PG, Coronado ENH, Hughes PDM, Huguet A, Kononen M, Laggoun-Defarge F, Lahteenoja O, Lamentowicz M, Marchant R, McClymont E, Pontevedra-Pombal X, Ponton C, Pourmand A, Rizzuti AM, Rochefort L, Schellekens J, De Vleeschouwer F, Pancost RD (2017) Introducing global peatspecific temperature and $\mathrm{pH}$ calibrations based on brGDGT bacterial lipids. Geochimica et Cosmochimica Acta 208:285-301. https://doi. org/10.1016/j.gca.2017.01.038

Nottingham AT, Griffiths H, Chamberlain PM, Stott AW, Tanner EVJ (2009) Soil priming by sugar and leaf-litter substrates: a link to microbial groups. Applied soil ecology 42:183-190. https://doi. org/10.1016/j.apsoil.2009.03.003

Nurulita Y, Adetutu EM, Gunawan H, Zul D, Ball AS (2016) Restoration of tropical peat soils: the application of soil microbiology for monitoring the success of the restoration process. Agriculture Ecosystems \& Environment 216:293-303. https://doi.org/10.1016/ j.agee.2015.09.031

Orwin KH, Dickie IA, Holdaway R, Wood JR (2018) A comparison of the ability of PLFA and 16S rRNA gene metabarcoding to resolve soil community change and predict ecosystem functions. Soil Biology and Biochemistry. https://doi.org/10.1016/j.soilbio.2017. 10.036

Page SE, Rieley JO, Banks CJ (2011) Global and regional importance of the tropical peatland carbon pool. Global Change Biology. https:// doi.org/10.1111/j.1365-2486.2010.02279.x

Pancost RD, Damste JSS (2003) Carbon isotopic compositions of prokaryotic lipids as tracers of carbon cycling in diverse settings. Chemical Geology 195:29-58. https://doi.org/10.1016/S00092541(02)00387-X

Phillips S, Rouse GE, Bustin RM (1997) Vegetation zones and diagnostic pollen profiles of a coastal peat swamp, Bocas del Toro, Panama. Palaeogeography, Palaeoclimatology, Palaeoecology 128:301-338

Ramsey PW, Rillig MC, Feris KP, Holben WE, Gannon JE (2006) Choice of methods for soil microbial community analysis: PLFA maximizes 
power compared to CLPP and PCR-based approaches. Pedobiologia. https://doi.org/10.1016/j.pedobi.2006.03.003

Reddy KR, DeLaune RD (2008) Biogeochemistry of wetlands: science and applications. CRC, Boca Raton

Roslev P, Iversen N (1999) Radioactive fingerprinting of microorganisms that oxidize atmospheric methane in different soils. Applied and Environmental Microbiology 65:4064-4070

Schouten S, Hopmans EC, Pancost RD, Damste JSS (2000) Widespread occurrence of structurally diverse tetraether membrane lipids: evidence for the ubiquitous presence of low-temperature relatives of hyperthermophiles. Proceedings of the National Academy of Sciences of the United States of America 97:14421-14426. https:// doi.org/10.1073/pnas.97.26.14421

Schouten S, van der Meer MTJ, Hopmans EC, Rijpstra WIC, Reysenbach AL, Ward DM, Damste JSS (2007) Archaeal and bacterial glycerol dialkyl glycerol tetraether lipids in hot springs of Yellowstone national park. Applied and Environmental Microbiology 73:61816191. https://doi.org/10.1128/Aem.00630-07

Singh BK, Tate KR, Kolipaka G, Hedley CB, Macdonald CA, Millard P, Murrell JC (2007) Effect of afforestation and reforestation of pastures on the activity and population dynamics of methanotrophic bacteria. Applied and Environmental Microbiology 73:5153-5161. https://doi.org/10.1128/Aem.00620-07

Sjögersten S, Black CR, Evers S, Hoyos-Santillan J, Wright EL, Turner BL (2014) Tropical wetlands: a missing link in the global carbon cycle? Global biogeochemical cycles 28:1371-1386. https://doi.org/ 10.1002/2014gb004844

Sjögersten S, Cheesman AW, Lopez O, Turner LB (2011) Biogeochemical processes along a nutrient gradient in a tropical ombrotrophic peatland. Biogeochemistry 104:147-163. https://doi. org/10.1007/s10533-010-9493-7

Smith TEL, Evers S, Yule CM, Gan JY (2018) In situ tropical Peatland fire emission factors and their variability, as determined by field measurements in peninsula Malaysia. Global Biogeochemical Cycles. https://doi.org/10.1002/2017GB005709

Tavi NM, Martikainen PJ, Lokko K, Kontro M, Wild B, Richter A, Biasi C (2013) Linking microbial community structure and allocation of plant-derived carbon in an organic agricultural soil using (CO2)-C13 pulse-chase labelling combined with C-13-PLFA profiling. Soil Biology \& Biochemistry 58:207-215. https://doi.org/10.1016/j. soilbio.2012.11.013

Thormann MN (2006) Diversity and function of fungi in peatlands: a carbon cycling perspective. Canadian journal of soil science 86 : 281-293. https://doi.org/10.4141/S05-082

Troxler TG, Ikenaga M, Scinto L, Boyer JN, Condit R, Perez R, Gann GD, Childers DL (2012) Patterns of soil Bacteria and canopy community structure related to tropical Peatland development. Wetlands 32:769-782. https://doi.org/10.1007/s13157-012-0310-z

Upton A, Vane CH, Girkin N, Turner BL, Sjögersten S (2018) Does litter input determine carbon storage and peat organic chemistry in tropical peatlands? Geoderma 326:76-87. https://doi.org/10.1016/j. geoderma.2018.03.030

Vanesa S, Carolina R, Alejandra RM, Gabriela C, Alicia G, Adriana AR, Sebastian F (2013) Fungal root colonization of Puccinellia frigida
(Phil.) Johnston, a dominant grass species inhabiting the margins of high-altitude hypersaline Andean wetlands. Aquatic Botany 108: 26-32. https://doi.org/10.1016/j.aquabot.2013.03.001

Wang YT, Qiu Q, Yang ZY, Hu ZJ, Tam NFY, Xin GR (2010) Arbuscular mycorrhizal fungi in two mangroves in South China. Plant and Soil 331:181-191. https://doi.org/10.1007/s11104-009-0244-2

Weijers JWH, Schouten S, Hopmans EC, Geenevasen JAJ, David ORP, Coleman JM, Pancost RD, Damste JSS (2006) Membrane lipids of mesophilic anaerobic bacteria thriving in peats have typical archaeal traits. Environmental Microbiology 8:648-657. https://doi.org/10. 1111/j.1462-2920.2005.00941.x

White D, Bobbie R, King J, Nickels J, Amoe P (2009) Lipid analysis of sediments for microbial biomass and community structure, in: methodology for biomass determinations and microbial activities in sediments. 10.1520/stp38143s

Willers C, Jansen van Rensburg PJ, Claassens S (2015) Microbial signature lipid biomarker analysis - an approach that is still preferred, even amid various method modifications. Journal of Applied Microbiology. https://doi.org/10.1111/jam.12798

Wright EL, Black CR, Cheesman AW, Drage T, Large D, Turner BL, SjöGersten S (2011) Contribution of subsurface peat to CO2 and CH4 fluxes in a neotropical peatland. Global Change Biology 17: 2867-2881. https://doi.org/10.1111/j.1365-2486.2011.02448.x

Wright EL, Black CR, Cheesman AW, Turner BL, Sjögersten S (2013a) Impact of Simulated Changes in Water Table Depth on Ex Situ Decomposition of Leaf Litter from a Neotropical Peatland. Wetlands 33:217-226. https://doi.org/10.1007/s13157-012-0369-6

Wright EL, Black CR, Turner BL, Sjögersten S (2013b) Environmental controls of temporal and spatial variability in $\mathrm{CO} 2$ and $\mathrm{CH} 4$ fluxes in a neotropical peatland. Global Change Biology. https://doi.org/10. $1111 /$ gcb. 12330

Xu ZY, Ban YH, Jiang YH, Zhang XL, Liu XY (2016) Arbuscular Mycorrhizal Fungi in wetland habitats and their application in constructed wetland: a review. Pedosphere 26:592-617. https://doi.org/ 10.1016/S1002-0160(15)60067-4

Yao HY, Chapman SJ, Thornton B, Paterson E (2015) C-13 PLFAs: a key to open the soil microbial black box? Plant and Soil 392:3-15. https://doi.org/10.1007/s11104-014-2300-9

Zhang ZH, Smittenberg RH, Bradley RS (2016) GDGT distribution in a stratified lake and implications for the application of TEX86 in paleoenvironmental reconstructions. Scientific reports 6 . Artn 34465https://doi.org/10.1038/Srep34465

Zheng YH, Li QY, Wang ZZ, Naafs BDA, Yu XF, Pancost RD (2015) Peatland GDGT records of Holocene climatic and biogeochemical responses to the Asian monsoon. Organic Geochemistry 87:86-95. https://doi.org/10.1016/j.orggeochem.2015.07.012

Zhong S, Zeng HC, Jin ZQ (2015) Soil microbiological and biochemical properties as affected by different long-term Banana-based rotations in the tropics. Pedosphere 25:868-877

Publisher's Note Springer Nature remains neutral with regard to jurisdictional claims in published maps and institutional affiliations. 